U.S. DEPARTMENT OF THE INTERIOR

U.S. GEOLOGICAL SURVEY

\title{
WIDE-ANGLE SEISMIC RECORDINGS OBTAINED DURING THE TACT MULTICHANNEL REFLECTION PROFILING IN THE NORTHERN GULF OF ALASKA
}

By

Thomas M. Brocher ${ }^{1}$ and Michael J. Moses ${ }^{1}$

Open-File Report 90-663

1345 Middlefield Road, M/S 977, Menlo Park, CA 94025

This report is preliminary and has not been reviewed for conformity with U.S. Geological Survey editorial standards or with the North American Stratigraphic Code. Any use of trade, product or firm names is for descriptive purposes only and does not imply endorsement by the U.S. Government.

Menlo Park, California

1990 


\section{CONTENTS}

$\begin{array}{lr}\text { Abstract } & 2 \\ \text { Introduction and Objectives } & 2 \\ \text { The Source Array } & 4 \\ \text { Recorder Locations } & 5 \\ \text { Deployment Logistics } & 5 \\ \text { Sonobuoy and GEOS Operations } & 8 \\ \text { Shot Instant Timing } & 12 \\ \text { Navigation } & 21 \\ \text { Data Reduction } & 21 \\ \text { Record Sections } & 22 \\ \text { Acknowledgements } & 31 \\ \text { Appendix: Data Reduction } & 31 \\ \text { References } & 40\end{array}$

FIGURES

Figure 1. Location map of northern Gulf of Alaska 3

Figure 2. Sonobuoy locations $\quad 14$

Figure 3. Record section showing Pn arrivals 27

Figure 4. Receiver gather showing prominent $6 \mathrm{~s}$ reflector 28

Figure 5. Example of converted shear wave arrivals 29

Figure 6. Example of a sonobuoy record 30

\section{TABLES}

Table 1. 5-day Recorder Locations and Elevations 6

Table 2. 5-day Recorder Times of Operation 7

Table 3. R/V Geotide Airgun Firing Times and Locations 9

Table 4. 5-day Recorder Seismometer Coupling 11

Table 5. R/V Big Valley GEOS Recording Times 13

Table 6. Sonobuoy Locations 16

Table 7. Wide-angle Seismic Profiles 24 


\begin{abstract}
During the first two weeks in July, 1988, the U.S. Geological Survey simultaneously acquired $1100 \mathrm{~km}$ of marine multichannel seismic reflection and wide-angle reflection/refraction data along 6 profiles in the northern Gulf of Alaska. These data were acquired for the multidisciplinary Trans-Alaska Crustal Transect (TACT) using a large (7770 cu. in.) airgun array. A temporary array of seismic stations located throughout Prince William Sound and the northern Gulf of Alaska recorded the airgun signals, generated at $50 \mathrm{~m}$ intervals along the reflection lines, as wide angle reflections and refractions. Sixteen three-component land stations continuously recorded the airgun signals. Two marine stations designed to reverse the ray coverage were also obtained using expendable military sonobuoys recorded at a nearby ship dedicated for that purpose. Over 65 wide-angle seismic profiles, having either an in-line or fan geometry, were acquired during the experiment. This report describes the experiment, provides the locations and times of operation of all the recorders, presents the scheme followed to reduce the data, and provides examples of the recorded wide-angle seismic data.
\end{abstract}

\title{
INTRODUCTION AND OBJECTIVES
}

In July, 1988, the U.S. Geological Survey (USGS) simultaneously acquired 1100 $\mathrm{km}$ of marine multichannel seismic reflection and wide-angle reflection/refraction data along 6 profiles in the northern Gulf of Alaska using the R/V Geotide operated by Digicon. These data were acquired using a large $(7770 \mathrm{cu}$. in.) airgun array for the multidisciplinary Trans-Alaska Crustal Transect (TACT) study being conducted across Alaska (Page et al., 1986). The reflection and wide-angle profiling in the Gulf of Alaska was designed to extend the deep crustal structure already mapped onshore by TACT to offshore regions and to map the crustal structure of the accretionary margin off southern Alaska to the Aleutian Trench. The primary objective of the wide-angle seismic recording was to obtain velocity control on the mid-to-lower crustal reflections imaged by the multichannel seismic reflection profiling in the northern Gulf of Alaska. Another major goal of the wide-angle profiling was to obtain constraints on the crustal thickness and geometry of the subducting Pacific plate beneath the southern Alaska margin. The airgun signals, generated at $50 \mathrm{~m}$ intervals along the TACT project reflection lines, were recorded by a temporary array of 18 seismic recorders located throughout Prince William Sound and the northern Gulf of Alaska (Figure 1).

Sixteen temporary three-component land stations recorded signals continuously during the entire experiment. Two stations were located offshore and used GEOS instruments to record expendable military sonobuoys from a nearby ship dedicated to this purpose. Over 65 wide-angle seismic profiles, having either an in-line or fan geometry, were acquired during the experiment. 


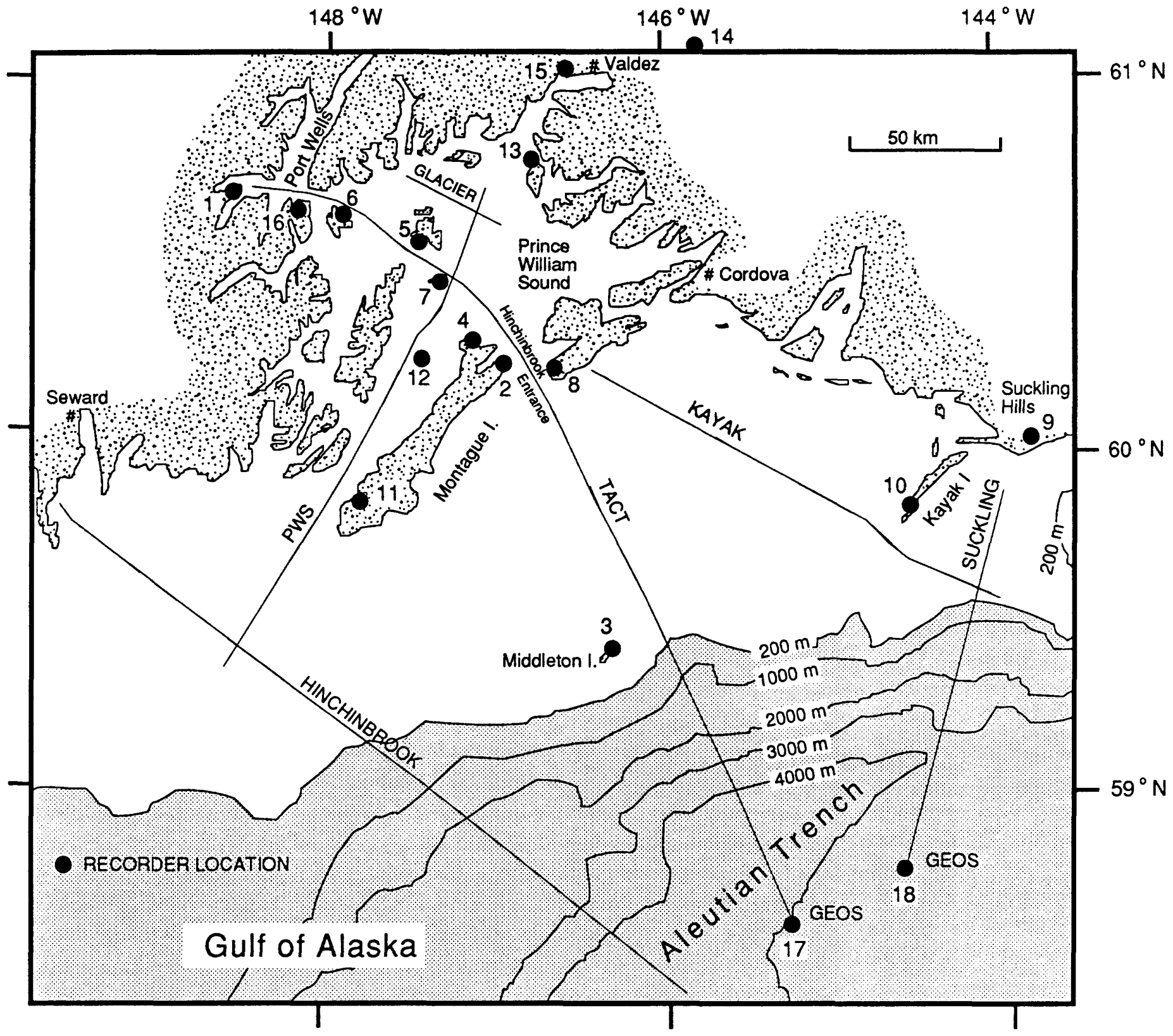

Figure 1. Location map of Prince William Sound and the northern Gulf of Alaska showing the locations of the TACT reflection lines and temporary seismic recorders. 
Funding limitations and the need to obtain wide-angle data on a non-interference basis with respect to the reflection profiling restricted our options for recording the airgun sources. For this reason, and for other logistical concerns, we used existing analog USGS recorders, capable of recording continuously for 5 days.

We concentrated our efforts on obtaining several wide-angle recordings along the TACT reflection line (Figure 1). This line provides the most direct connection between previous TACT onshore seismic refraction and reflection results and the crustal structure of the southern Alaskan margin. The TACT line crosses the Contact Fault bounding the Chugach and Prince William terranes near Port Wells, traverses the Prince William terrane through Hinchinbrook Entrance past Middleton Island, and crosses onto the Yakutat terrane just prior to running onto the Pacific Plate (Figure 1).

The large number of islands within Prince William Sound allowed us to deploy 14 temporary stations along the PWS line. The PWS line ties the HINCHINBROOK and TACT lines and images the crustal structure beneath the Prince William terrane (Figure 1). Of the 14 recordings obtained for this line, half are in a fan geometry and half are in-line profiles.

Nearly all of the same temporary stations deployed for the TACT line were also used to record the KAYAK line, which was oriented orthogonal to the Kayak Zone, the terrane boundary between the Prince William and Yakutat terranes. The offshore location of the Kayak Zone has been defined by reflection profiling in the northem Gulf of Alaska (Bruns, 1985).

The SUCKLING line was designed to image the crustal structure within the Yakutat terrane and the subducting oceanic plate south of the Suckling Hills (Figure 1). Although logistical difficulties made it impossible for us to deploy more than a few seismic stations along this line, Site 9 and offshore GEOS Site 18 were occupied specifically to provide reversed refraction control along this line.

Thirteen stations recorded the short, unplanned GLACIER line which substituted for stopping the PWS line south of Valdez Arm. The GLACIER line was acquired subparallel to the TACT line to provide cross-line control on reflector dips on the PWS line (Figure 1).

The long HINCHINBROOK line, designed to map the crustal structure within the Prince William terrane and to image the Contact Fault just north of Seward, Alaska, was not recorded by in-line stations. Seven land-based stations, however, recorded parts of this line in a fan geometry.

\section{THE SOURCE ARRAY}

The airgun array provided by Digicon on the $\mathrm{R} / \mathrm{V}$ Geotide consisted of a 40 element array totalling $7770 \mathrm{cu}$. in. operated at 2000 PSI. The nominal calculated primary to bubble pulse ratio for this array is 9.7. The array generated a nominal peak-to-peak pressure calculated to be 178 bar-m. This airgun array is nearly 
identical to that used by Project GLIMPCE investigators in the Great Lakes of North America to image deep crustal structure (Lee et al., 1988).

\section{RECORDER LOCATIONS}

The land stations were USGS three-component 5-day instruments which record continuously on $1 / 2$ inch analog magnetic tape. The operation of these instruments has been described by Criley and Eaton (1978). One vertical and two horizontal 1 $\mathrm{Hz}$ seismometers (NS and EW) were recorded at all land stations. These instruments are frequently used by the USGS for earthquake aftershock studies and teleseismic studies of lithospheric structure.

The 5-day recorders were deployed in 16 locations in the vicinity of Prince William Sound, the Suckling Hills, Middleton Island, and the Chugach Mountains (Figure 1). The recorders were deployed at 20 to $30 \mathrm{~km}$ intervals along the TACT and PWS reflection lines to provide a reconnaissance survey of the crustal structure along these lines. The 5-day recorder locations were determined using a combination of air photographs (at scales of 1:50,000 and less), USGS topographic maps at a scale of 1:63,360, and Loran-C. The locations and elevations of the land recorders are provided in Table 1. Locations determined from the air photographs and topographic maps agreed to within $+/-0.2$ minutes $(400 \mathrm{~m})$ of the Loran-C readings. We attribute the location misfit to the difficulty in receiving Loran-C in parts of the study area. Based on a more recent comparison of 19 locations determined using both topographic maps and a Global Positioning Satellite receiver (GPS) in central California, we estimate that uncertainties in the recorder locations in Alaska are about $40+/$ $15 \mathrm{~m}$ and that the average uncertainty in recorder elevations is about $8 \mathrm{~m}$.

Four of the land stations were deployed to reoccupy shotpoints used to acquire seismic refraction profiles onshore (Wilson et al., 1987). These included Zaikof Point (Site 2) and Hanning Bay on Montague Island (Site 11), Stuart Creek (Site 14), and Shoup Bay (Site 15). The 5-day recorder locations at these sites were within a few hundred meters of the explosive shotpoints.

\section{DEPLOYMENT LOGISTICS}

The 5-day recorders were deployed by helicopter from Valdez, Alaska. Instruments were first ferried from Valdez to a temporary storage site and fuel cache on Naked Island (Site 5) in Prince William Sound. From Naked Island seismic recorders were deployed to other locations. Upon notification of the beginning of the TACT line by the R/V Geotide the 5-day stations were revisited and the continuous recording was started (Table 2). Because the experiment lasted 9 days, it was necessary to visit each station at least once during the study to refurbish batteries and magnetic tapes. This extra trip to each station was also required by the fact that the TACT and PWS lines were acquired in segments, separated in time by intervals up to 
Table 1. 5-day Recorder Locations and Elevations

\begin{tabular}{llllr}
$\begin{array}{l}\text { Site } \\
\text { No. }\end{array}$ & $\begin{array}{l}\text { Station } \\
\text { Name }\end{array}$ & $\begin{array}{c}\text { Latitude }(\mathrm{N}) \\
\text { Deg. Min. }\end{array}$ & $\begin{array}{c}\text { Longitude (W) } \\
\text { Deg. Min. }\end{array}$ & $\begin{array}{c}\text { Elevation } \\
(\mathrm{m})\end{array}$ \\
\hline & & & & \\
1 & Whittier & 6047.972 & 14831.685 & $3+/-2$ \\
2 & Zaikof Pt. & 6017.970 & 14655.720 & $84+/-8$ \\
3 & Middleton Isl. & 5927.160 & 14618.340 & $26+/-3$ \\
4 & Montague Isl. & 6022.075 & 14706.920 & $99+/-8$ \\
5 & Naked Isl. & 6037.505 & 14727.550 & $160+/-8$ \\
6 & Perry Isl. & 6043.850 & 14754.600 & $259+/-8$ \\
7 & Smith Isl. & 6031.800 & 14720.550 & $2+/-1$ \\
8 & Signal Mtn. & 6016.575 & 14640.160 & $361+/-2$ \\
9 & Suckling Hills & 6004.890 & 14347.150 & $274+/-8$ \\
10 & Kayak Isl. & 5952.440 & 14429.420 & $244+/-15$ \\
11 & Hanning Bay & 5956.530 & 14742.340 & $130+/-8$ \\
12 & Green Isl. & 6015.430 & 14729.890 & $2+/-1$ \\
13 & Busby Isl. & 6053.635 & 14648.440 & $3+/-2$ \\
14 & Stuart Creek & 6115.275 & 14517.130 & $369+/-3$ \\
15 & Shoup Bay & 6109.280 & 14636.400 & $15+/-8$ \\
16 & Culross Isl. & 6045.160 & 14812.560 & $99+/-8$ \\
\hline
\end{tabular}


Table 2. 5-day Recorder Times of Operation

\begin{tabular}{|c|c|c|c|}
\hline $\begin{array}{l}\text { Site } \\
\text { No. } \\
\end{array}$ & $\begin{array}{l}\text { Station } \\
\text { Name } \\
\end{array}$ & $\begin{array}{c}\text { GMT Time On } \\
\text { JD HRMIN }\end{array}$ & $\begin{array}{c}\text { GMT Time Off } \\
\text { JD HRMIN } \\
\end{array}$ \\
\hline \multirow[t]{3}{*}{1} & Whittier & 1840243 & 1881817 \\
\hline & & 1881843 & 1890145 \\
\hline & & 1910014 & 1941856 \\
\hline \multirow[t]{3}{*}{2} & Zaikof Pt. & 1832240 & 1872150 \\
\hline & & 1872206 & 1890034 \\
\hline & & 1902257 & 1952034 \\
\hline \multirow[t]{2}{*}{3} & Middleton Isl. & 1860000 & 1882025 \\
\hline & & 1882049 & 1931500 \\
\hline \multirow[t]{4}{*}{4} & Montague Isl. & 1832345 & 1872254 \\
\hline & & 1872315 & 1890045 \\
\hline & & 1902314 & 1932347 \\
\hline & & 1932354 & 1952131 \\
\hline \multirow[t]{3}{*}{5} & Naked Isl. & 1840414 & 1880005 \\
\hline & & 1880023 & 1890114 \\
\hline & & 1910116 & 1950029 \\
\hline \multirow[t]{3}{*}{6} & Perry Isl. & 1840134 & 1881648 \\
\hline & & 1881711 & 1890129 \\
\hline & & 1910055 & 1942039 \\
\hline \multirow[t]{2}{*}{7} & Smith Isl. & 1842201 & 1890100 \\
\hline & & 1900325 & 1942352 \\
\hline \multirow[t]{3}{*}{8} & Signal Mtn. & 1832145 & 1872032 \\
\hline & & 1872058 & 1890025 \\
\hline & & 1902239 & 1931749 \\
\hline 9 & Suckling Hills & 1852340 & 1901847 \\
\hline 10 & Kayak Isl. & 1860300 & 1902004 \\
\hline 11 & Hanning Bay & 1900140 & 1942219 \\
\hline 12 & Green Isl. & 1892258 & 1942307 \\
\hline \multirow[t]{3}{*}{13} & Busby Isl. & 1870239 & 1881943 \\
\hline & & 1910208 & 1940159 \\
\hline & & 1940216 & 1960012 \\
\hline \multirow[t]{2}{*}{14} & Stuart Creek & 1860400 & 1902347 \\
\hline & & 1910011 & 1941600 \\
\hline \multirow[t]{3}{*}{15} & Shoup Bay & 1870201 & 1882000 \\
\hline & & 1910340 & 1940323 \\
\hline & & 1940340 & 1960157 \\
\hline \multirow[t]{2}{*}{16} & Culross Isl. & 1850134 & 1890230 \\
\hline & & 1910037 & 1941949 \\
\hline
\end{tabular}


5 days (Table 3). At the end of the experiment all the stations were removed leaving no permanent markers at any site.

Deploying stations at Suckling Hills (Site 9) and Kayak Island (Site 10) from Valdez required refueling the helicopter at Cordova, Alaska. The Aviation Support Facility of the Cordova Coast Guard Station kindly made this fuel available to us as well as a work space to allow the preparation of recorders. Although the Suckling Hills station (Site 9) was designed to reoccupy the site of a former Alaska earthquake network station, logistical concerns made this reoccupation impractical. Thus, the 5-day station was relocated to a slightly lower elevation about $1 \mathrm{~km} \mathrm{NW}$ of the designed location.

The 5-day recorder on Middleton Island (Site 3) was transported by a twin-engine fixed-wing aircraft. The Federal Aviation Administration (FAA) in Kenai, Alaska, made space available for us on three round-trip flights to Middleton Island which allowed us to deploy, refresh, and recover the 5-day recorder. FAA employees on the island tumed on the recorder upon notification of the start of reflection profiling.

Care was taken while deploying the seismometers to avoid boggy tundra or swampy ground and to attempt to locate the seismometers on hard rock outcrops. Nearly $80 \%$ of the 5-day recorder sites were located on hard rock outcrops; to insure coupling the seismometers were literally plastered onto the rock (Table 4). At only 2 sites were seismometers buried in soil or alluvium. The high-quality of the data recorded at the hard rock sites suggests that this technique was successful.

Excellent flying conditions for the length of the experiment allowed the complex logistical arrangements to be completed as planned. While recorders located at higher elevations would have been difficult to deploy, no significant helicopter time was lost due to low cloud cover or poor weather.

\section{SONOBUOY AND GEOS OPERATIONS}

In addition to the onshore recording, offshore recording was performed in two locations in an attempt to reverse the land-based wide-angle coverage. The 91-foot R/V Big Valley was used to record signals transmitted by expendable military sonobuoys in two locations at the seaward ends of the TACT and SUCKLING lines (Sites 17 and 18 on Figure 1).

Data were recorded at these offshore locations using free-floating expendable military sonobuoys (Model SSQ-57A). The sonobuoy transmissions were received using a broadbeam antenna mounted on the wheelhouse of the R/V Big Valley. A Yaesu VHF/UHF Communications Receiver (Model FRG-9600), modified to pass frequencies below the audio band, was used to transform the FM sonobuoy signal into an analog electrical signal. The analog signal was input to a USGS GEOS recorder, which digitized and recorded the signal at a 100 $\mathrm{Hz}$ sample rate. Signal levels were monitored using an oscilloscope throughout the experiment and gains were increased as source-receiver offsets increased. To our knowledge, this experiment represented the first use of the GEOS recorder in the marine environment, demonstrating the flexibility and highly programmable aspect of the GEOS recorder (Borcherdt et al., 1985). An onboard playback unit was used to verify that valid data were recorded 
Table 3. R/V GEOTIDE Airgun Firing Times and Locations

TACT Line

\begin{tabular}{rrrrrr}
$\begin{array}{r}\text { GMT Begin } \\
\text { JD HRMIN }\end{array}$ & $\begin{array}{r}\text { Lat. (N) } \\
\text { Deg. Min. }\end{array}$ & $\begin{array}{r}\text { Long. (W) } \\
\text { Deg. Min. }\end{array}$ & $\begin{array}{r}\text { GMT End } \\
\text { JD HRMIN }\end{array}$ & $\begin{array}{r}\text { Lat. (N) } \\
\text { Deg. Min. }\end{array}$ & $\begin{array}{r}\text { Long. (W) } \\
\text { Deg. Min. }\end{array}$ \\
\hline 1860155 & 5836.901 & 14515.892 & 1860840 & 5901.550 & 14536.163 \\
1861204 & 5858.070 & 14533.272 & 1861345 & 5905.250 & 14539.237 \\
1861754 & 5903.536 & 14537.796 & 1871053 & 6009.994 & 14642.116 \\
1921734 & 6024.737 & 14658.296 & 1922137 & 6008.110 & 14640.307 \\
1930201 & 6024.754 & 14658.336 & 1931301 & 6047.359 & 14824.516
\end{tabular}

KAYAK Line

\begin{tabular}{rrrrrr}
$\begin{array}{r}\text { GMT Begin } \\
\text { JD HRMIN }\end{array}$ & $\begin{array}{r}\text { Lat. (N) } \\
\text { Deg. Min. }\end{array}$ & $\begin{array}{r}\text { Long. (W) } \\
\text { Deg. Min. }\end{array}$ & $\begin{array}{r}\text { GMT End } \\
\text { JD HRMIN }\end{array}$ & $\begin{array}{r}\text { Lat. (N) } \\
\text { Deg. Min. }\end{array}$ & $\begin{array}{r}\text { Long. (W) } \\
\text { Deg. Min. }\end{array}$ \\
\hline 1871647 & 6015.709 & 14625.992 & 1880532 & 5947.673 & 14447.545 \\
1881255 & 5948.253 & 14449.352 & 1881857 & 5934.477 & 14402.962
\end{tabular}

SUCKLING Line

GMT Begin Lat. (N) Long. (W) GMT End Lat. (N) Long. (W)

\begin{tabular}{rrrrrr} 
JD HRMIN & Deg. Min. & Deg. Min. & JD HRMIN & Deg. Min. & Deg. Min. \\
\hline 1890001 & 5953.528 & 14400.758 & 1891449 & 5847.377 & 14437.124
\end{tabular}

HINCHINBROOK Line

\begin{tabular}{rrrrrr}
$\begin{array}{r}\text { GMT Begin } \\
\text { JD HRMIN }\end{array}$ & $\begin{array}{r}\text { Lat. (N) } \\
\text { Deg. Min. }\end{array}$ & $\begin{array}{r}\text { Long. (W) } \\
\text { Deg. Min. }\end{array}$ & $\begin{array}{r}\text { GMT End } \\
\text { JD HRMIN }\end{array}$ & $\begin{array}{r}\text { Lat. (N) } \\
\text { Deg. Min. }\end{array}$ & $\begin{array}{r}\text { Long. (W) } \\
\text { Deg. Min. }\end{array}$ \\
\hline 1900010 & 5825.212 & 14552.487 & 1910806 & 5950.515 & 14932.622
\end{tabular}

PWS Line

\begin{tabular}{rrrrrr}
$\begin{array}{r}\text { GMT Begin } \\
\text { JD HRMIN }\end{array}$ & $\begin{array}{r}\text { Lat. (N) } \\
\text { Deg. Min. }\end{array}$ & $\begin{array}{c}\text { Long. (W) } \\
\text { Deg. Min. }\end{array}$ & $\begin{array}{r}\text { GMT End } \\
\text { JD HRMIN }\end{array}$ & $\begin{array}{r}\text { Lat. (N) } \\
\text { Deg. Min. }\end{array}$ & $\begin{array}{r}\text { Long. (W) } \\
\text { Deg. Min. }\end{array}$ \\
\hline 1912207 & 5921.731 & 14832.462 & 1921509 & 6029.897 & 14716.283 \\
1932351 & 6028.950 & 14717.606 & 1940357 & 6047.455 & 14703.172
\end{tabular}


Table 3 Continued. R/V GEOTIDE Airgun Firing Times and Locations

\section{GLACIER Line}

\begin{tabular}{rrrrrr}
$\begin{array}{c}\text { GMT Begin } \\
\text { JD HRMIN }\end{array}$ & $\begin{array}{r}\text { Lat. (N) } \\
\text { Deg. Min. }\end{array}$ & $\begin{array}{c}\text { Long. (W) } \\
\text { Deg. Min. }\end{array}$ & $\begin{array}{r}\text { GMT End } \\
\text { JD HRMIN }\end{array}$ & $\begin{array}{r}\text { Lat. (N) } \\
\text { Deg. Min. }\end{array}$ & $\begin{array}{r}\text { Long. (W) } \\
\text { Deg. Min. }\end{array}$ \\
\hline 1940912 & 6049.080 & 14733.061 & 1941312 & 6041.173 & 14657.195
\end{tabular}


Table 4. 5-day Recorder Seismometer Coupling

Site Station

No. Name

Seismometer Plant Description

1 Whittier Plastered onto bare rock outcrop

6 Perry Isl.

"I

7 Smith Isl. "

8 Signal Mtn. "

12 Green Isl. "

13 Busby Isl. "

14 Stuart Creek "

15 Shoup Bay "

2 Zaikof Pt. Plastered onto buried hard rock

4 Montague Isl. "

5 Naked Isl. "

11 Hanning Bay "

16 Culross Isl. "

9 Suckling Hills Plastered onto weathered rock outcrop

3 Middleton Isl. Buried in coarse alluvium

10 Kayak Isl. Buried in soil 
during the experiment. Table 5 provides a listing of the tapes recorded in this manner for the TACT, KAYAK, and SUCKLING reflection lines. Playback of the 600 -foot GEOS tapes was performed using the RSGEOS program written by Gary Maxwell. These files were converted to SEG-Y format and written to 6250 BPI magnetic tape.

Prior to launching the sonobuoys, the buoys were outfitted with colorful flagging and strobe lights (at night) so that their position could be monitored from the ship for a distance up to about $200 \mathrm{~m}$. The monitoring of the sonobuoy location proved important due to the 0.3 to 1 knot currents in the study area. The Loran-C location of the ship and the position of the sonobuoy relative to the ship were recorded at 30 minute intervals. Sonobuoy locations for the experiment for both the TACT and SUCKLING lines are plotted in Figure 2 and are given in Table 6.

Due to the limited number of sonobuoys available for the experiment, the KAYAK line was recorded in a fan geometry at the seaward end of the TACT line at Site 17 using a hydrophone deployed over the side of the R/V Big Valley at a depth of about 30 feet. High amplitude shipboard noises precluded recognition of seismic arrivals during the recording of the KAYAK line. The drift of the R/V Big Valley during the KAYAK line is shown in Figure 2. After the TACT and KAYAK lines were recorded at the endpoint of the TACT line, the R/V Big Valley sailed to the projected end of the SUCKLING line where the SUCKLING line was recorded at Site 18.

\section{SHOT INSTANT TIMING}

A time base common to all 18 seismic recorders and the multichannel source vessel was provided by three identical Kinemetric True-Time Satellite Clock Receivers (Model 468), each set with a propagation delay of $55 \mathrm{msec}$. Shot instant times on the $R / V$ Geotide were obtained by splitting the signal used as the origin time for the multichannel reflection data and sending a TTY signal to the Kinemetric receiver to request the time. These shot instant times, accurate to within a millisecond, were output to a line printer onboard the $\mathrm{R} / \mathrm{V}$ Geotide.

Identical Kinemetric Clock Receivers were also located in Valdez and on the $\mathrm{R} / \mathrm{V}$ Big Valley to allow the synchronization of the shot instant times with the landand marine-based wide-angle recordings. Accurate times were loaded into the 5-day and GEOS recorders using USGS Master Clock IIs. A Master Clock II drifts less than $1 \mathrm{~ms} /$ day and can display the time offset between itself and the Kinemetric Clock Receiver. After synchronizing with the Kinemetric Clock Receiver time, the Master Clock II time was loaded onto the beginning and end of each 5-day tape. Similarly, the clocks of the GEOS recorder and the Master Clock II were regularly compared during the experiment. The clock internal to the GEOS recorder used in this experiment experienced less than 1 or $2 \mathrm{~ms}$ drift during the entire experiment. 
Table 5. R/V BIG VALLEY GEOS Recording Times

\begin{tabular}{clccc}
$\begin{array}{c}\text { Site } \\
\text { Number }\end{array}$ & $\begin{array}{l}\text { Reflection } \\
\text { Line Name }\end{array}$ & $\begin{array}{c}\text { GEOS Tape } \\
\text { Number }\end{array}$ & $\begin{array}{c}\text { GMT Begin } \\
\text { JD HRMIN }\end{array}$ & $\begin{array}{r}\text { GMT End } \\
\text { JD HRMIN }\end{array}$ \\
\hline \multirow{3}{*}{17} & & & & \\
& TACT & 1 & 1860213 & 1860417 \\
& & 2 & 1860419 & 1861019 \\
& & 3 & 1861022 & 1861653 \\
& & 4 & 1861702 & 1862302 \\
& & 5 & 1862304 & 1870504 \\
17 & KAYAK & 7 & 1870507 & 1871700 \\
& & 8 & 1872015 & 1880215 \\
& & 9 & 1880218 & 1880848 \\
18 & SUCKLING & 10 & 1880850 & 1881840 \\
& & 11 & 1890717 & 1891317 \\
& & 12 & 1891319 & 1891500 \\
\hline
\end{tabular}



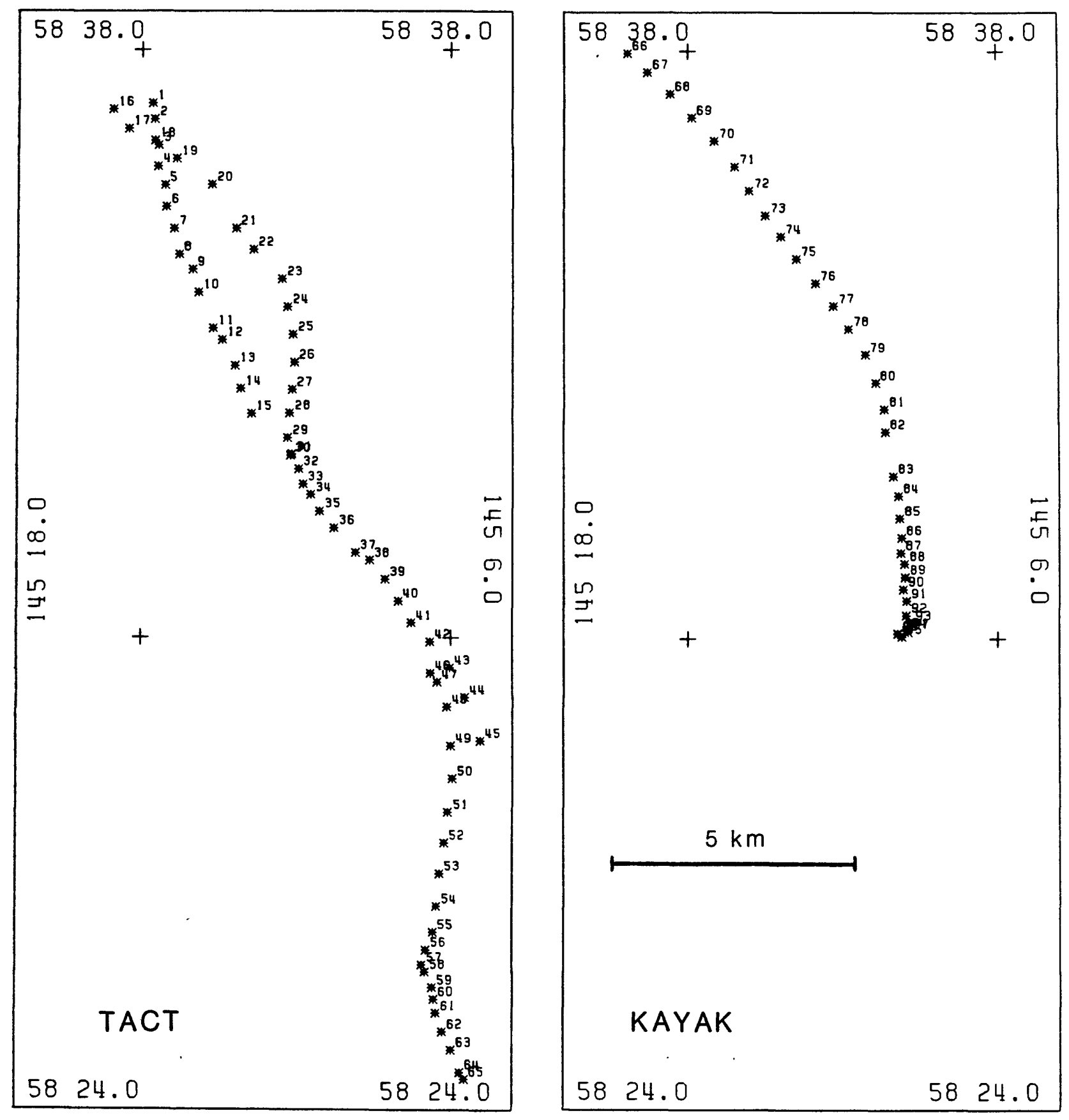

Figure 2. Location map of seaward end of the TACT line showing the drift of the sonobuoys and hydrophone recorded by the R/V Big Valley for this line and for the KAYAK line at Site 17. Table 6 provides the same information in numerical listings. 


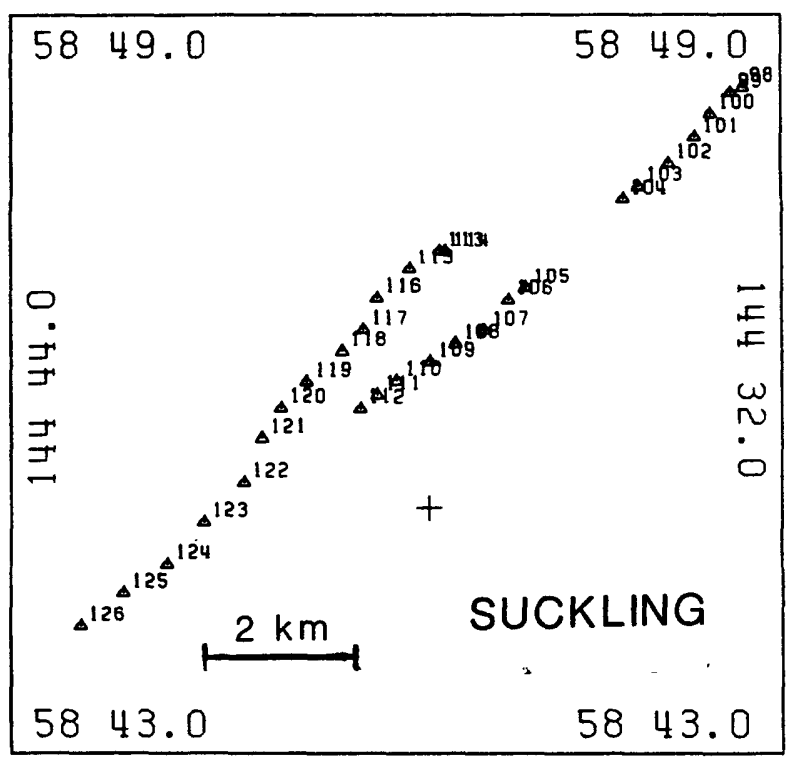

Figure 2 continued. Location map of seaward end of the SUCKLING line showing the drift of the sonobuoys recorded by the R/V Big Valley for this line at Site 18. Table 6 provides the same information in numerical listings. 
Table 6: Sonobuoy Times and Locations

SONOBUOY 1

\begin{tabular}{cccc}
$\begin{array}{c}\text { LOCATION } \\
\text { NUMBER }\end{array}$ & $\begin{array}{c}\text { GMT TIME } \\
\text { DAY/HR:MN }\end{array}$ & $\begin{array}{c}\text { LATITUDE } \\
\text { DEG MIN }\end{array}$ & $\begin{array}{c}\text { LONGITUDE } \\
\text { DEG MIN }\end{array}$ \\
\hline & & & \\
1 & $186 / 01: 30$ & 5836.810 & 14514.750 \\
2 & $186 / 02: 00$ & 5836.603 & 14514.689 \\
3 & $186 / 02: 30$ & 5836.273 & 14514.589 \\
4 & $186 / 03: 00$ & 5836.007 & 14514.599 \\
5 & $186 / 03: 30$ & 5835.768 & 14514.444 \\
6 & $186 / 04: 00$ & 5835.491 & 14514.405 \\
7 & $186 / 04: 30$ & 5835.214 & 14514.216 \\
8 & $186 / 05: 00$ & 5834.888 & 14514.091 \\
9 & $186 / 05: 30$ & 5834.693 & 14513.768 \\
10 & $186 / 06: 00$ & 5834.397 & 14513.627 \\
11 & $186 / 06: 30$ & 5833.946 & 14513.262 \\
12 & $186 / 07: 00$ & 5833.794 & 14513.043 \\
13 & $186 / 07: 30$ & 5833.471 & 14512.734 \\
14 & $186 / 08: 00$ & 5833.171 & 14512.594 \\
15 & $186 / 08: 30$ & 5832.845 & 14512.337
\end{tabular}

SONOBUOY 2

\begin{tabular}{cccc}
$\begin{array}{c}\text { LOCATION } \\
\text { NUMBER }\end{array}$ & $\begin{array}{c}\text { GMT TIME } \\
\text { DAY/HR:MN }\end{array}$ & $\begin{array}{c}\text { LATITUDE } \\
\text { DEG MIN }\end{array}$ & $\begin{array}{c}\text { LONGITUDE } \\
\text { DEG MIN }\end{array}$ \\
\hline & & & \\
16 & $186 / 09: 20$ & 5836.730 & 14515.700 \\
17 & $186 / 09: 30$ & 5836.482 & 14515.314 \\
18 & $186 / 10: 00$ & 5836.329 & 14514.687 \\
19 & $186 / 10: 30$ & 5836.102 & 14514.155 \\
20 & $186 / 11: 00$ & 5835.774 & 14513.300 \\
21 & $186 / 11: 30$ & 5835.214 & 14512.710 \\
22 & $186 / 12: 00$ & 5834.946 & 14512.289
\end{tabular}


SONOBUOY 3

\begin{tabular}{cccc}
$\begin{array}{c}\text { LOCATION } \\
\text { NUMBER }\end{array}$ & $\begin{array}{c}\text { GMT TIME } \\
\text { DAY/HR:MN }\end{array}$ & $\begin{array}{c}\text { LATITUDE } \\
\text { DEG MIN }\end{array}$ & $\begin{array}{c}\text { LONGITUDE } \\
\text { DEG MIN }\end{array}$ \\
\hline & & & \\
23 & $186 / 13: 00$ & 5834.570 & 14511.600 \\
24 & $186 / 13: 30$ & 5834.215 & 14511.459 \\
25 & $186 / 14: 00$ & 5833.871 & 14511.324 \\
26 & $186 / 14: 30$ & 5833.516 & 14511.298 \\
27 & $186 / 15: 00$ & 5833.162 & 14511.354 \\
28 & $186 / 15: 30$ & 5832.860 & 14511.404 \\
29 & $186 / 16: 00$ & 5832.545 & 14511.456 \\
30 & $186 / 16: 30$ & 5832.315 & 14511.386
\end{tabular}

SONOBUOY 4

\begin{tabular}{cccc}
$\begin{array}{c}\text { LOCATION } \\
\text { NUMBER }\end{array}$ & $\begin{array}{c}\text { GMT TIME } \\
\text { DAY/HR:MN }\end{array}$ & $\begin{array}{c}\text { LATITUDE } \\
\text { DEG MIN }\end{array}$ & $\begin{array}{c}\text { LONGITUDE } \\
\text { DEG MIN }\end{array}$ \\
\hline & & & \\
31 & $186 / 16: 30$ & 5832.330 & 14511.350 \\
32 & $186 / 17: 00$ & 5832.144 & 14511.192 \\
33 & $186 / 17: 30$ & 5831.949 & 14511.085 \\
34 & $186 / 18: 00$ & 5831.811 & 14510.893 \\
35 & $186 / 18: 30$ & 5831.605 & 14510.673 \\
36 & $186 / 19: 00$ & 5831.398 & 14510.323 \\
37 & $186 / 19: 30$ & 5831.088 & 1459.810 \\
38 & $186 / 20: 00$ & 5830.991 & 1459.468 \\
39 & $186 / 20: 30$ & 5830.750 & 1459.089 \\
40 & $186 / 21: 00$ & 5830.474 & 1458.775 \\
41 & $186 / 21: 30$ & 5830.190 & 1458.453 \\
42 & $186 / 22: 00$ & 5829.949 & 1457.996 \\
43 & $186 / 22: 30$ & 5829.619 & 1457.520 \\
44 & $186 / 23: 00$ & 5829.244 & 1457.160 \\
45 & $186 / 23: 52$ & 5828.695 & 1456.778
\end{tabular}




\section{SONOBUOY 5}

\begin{tabular}{cccc}
$\begin{array}{c}\text { LOCATION } \\
\text { NUMBER }\end{array}$ & $\begin{array}{c}\text { GMT TIME } \\
\text { DAY/HR:MN }\end{array}$ & $\begin{array}{c}\text { LATITUDE } \\
\text { DEG MIN }\end{array}$ & $\begin{array}{c}\text { LONGITUDE } \\
\text { DEG MIN }\end{array}$ \\
\hline 46 & $187 / 00: 22$ & 5829.550 & 1457.990 \\
47 & $187 / 00: 30$ & 5829.438 & 1457.827 \\
48 & $187 / 01: 00$ & 5829.123 & 1457.585 \\
49 & $187 / 01: 30$ & 5828.631 & 1457.484 \\
50 & $187 / 02: 00$ & 5828.210 & 1457.455 \\
51 & $187 / 02: 30$ & 5827.775 & 1457.566 \\
52 & $187 / 03: 00$ & 5827.385 & 1457.650 \\
53 & $187 / 03: 30$ & 5827.000 & 1457.765 \\
54 & $187 / 04: 00$ & 5826.583 & 1457.839 \\
55 & $187 / 04: 30$ & 5826.248 & 1457.923 \\
56 & $187 / 05: 00$ & 5826.024 & 1458.092 \\
57 & $187 / 05: 30$ & 5825.833 & 1458.189 \\
58 & $187 / 06: 00$ & 5825.744 & 1458.112 \\
59 & $187 / 06: 30$ & 5825.544 & 1457.937 \\
60 & $187 / 07: 00$ & 5825.396 & 1457.914 \\
61 & $187 / 07: 30$ & 5825.219 & 1457.848 \\
62 & $187 / 08: 00$ & 5824.985 & 1457.691 \\
63 & $187 / 08: 30$ & 5824.754 & 1457.472 \\
64 & $187 / 09: 00$ & 5824.473 & 1457.267 \\
65 & $187 / 09: 30$ & 5824.390 & 1457.167
\end{tabular}

HYDROPHONE FOR KAYAK LINE

\begin{tabular}{cccc}
$\begin{array}{c}\text { LOCATION } \\
\text { NUMBER }\end{array}$ & $\begin{array}{c}\text { GMT TIME } \\
\text { DAY/HR:MN }\end{array}$ & $\begin{array}{c}\text { LATITUDE } \\
\text { DEG MIN }\end{array}$ & $\begin{array}{c}\text { LONGITUDE } \\
\text { DEG MIN }\end{array}$ \\
\hline & & & \\
66 & $187 / 18: 00$ & 5837.470 & 14516.460 \\
67 & $187 / 18: 30$ & 5837.230 & 14515.970 \\
68 & $187 / 19: 00$ & 5836.960 & 14515.430 \\
69 & $187 / 19: 30$ & 5836.650 & 14514.900 \\
70 & $187 / 20: 00$ & 5836.350 & 14514.350 \\
71 & $187 / 20: 30$ & 5836.010 & 14513.860 \\
72 & $187 / 21: 00$ & 5835.700 & 14513.510 \\
73 & $187 / 21: 30$ & 5835.390 & 14513.110 \\
74 & $187 / 22: 00$ & 5835.120 & 14512.740 \\
75 & $187 / 22: 30$ & 5834.840 & 14512.370
\end{tabular}




$\begin{array}{llllll}76 & 187 / 23: 00 & 5834.530 & 145 & 11.900 \\ 77 & 187 / 23: 30 & 5834.240 & 145 & 11.470 \\ 78 & 188 / 00: 00 & 5833.950 & 145 & 11.100 \\ 79 & 188 / 00: 30 & 5833.620 & 145 & 10.700 \\ 80 & 188 / 01: 00 & 5833.260 & 145 & 10.450 \\ 81 & 188 / 01: 30 & 5832.920 & 145 & 10.230 \\ 82 & 188 / 02: 00 & 5832.630 & 145 & 10.210 \\ 83 & 188 / 03: 00 & 5832.070 & 145 & 10.020 \\ 84 & 188 / 03: 30 & 5831.820 & 145 & 9.900 \\ 85 & 188 / 04: 00 & 5831.530 & 145 & 9.860 \\ 86 & 188 / 04: 30 & 5831.280 & 145 & 9.820 \\ 87 & 188 / 05: 00 & 5831.090 & 145 & 9.840 \\ 88 & 188 / 05: 30 & 5830.950 & 145 & 9.750 \\ 89 & 188 / 06: 00 & 5830.780 & 145 & 9.740 \\ 90 & 188 / 06: 30 & 5830.630 & 145 & 9.780 \\ 91 & 188 / 07: 00 & 5830.480 & 145 & 9.710 \\ 92 & 188 / 07: 30 & 5830.300 & 145 & 9.710 \\ 93 & 188 / 08: 00 & 5830.200 & 145 & 9.600 \\ 94 & 188 / 08: 30 & 5830.110 & 145 & 9.700 \\ 95 & 188 / 09: 00 & 5830.030 & 145 & 9.820 \\ 96 & 188 / 10: 00 & 5830.070 & 145 & 9.910 \\ 97 & 188 / 10: 30 & 5830.090 & 145 & 9.660\end{array}$

\section{SONOBUOY 6}

\begin{tabular}{cccc}
$\begin{array}{c}\text { LOCATION } \\
\text { NUMBER }\end{array}$ & $\begin{array}{c}\text { GMT TIME } \\
\text { DAY/HR:MN }\end{array}$ & $\begin{array}{c}\text { LATITUDE } \\
\text { DEG MIN }\end{array}$ & $\begin{array}{c}\text { LONGITUDE } \\
\text { DEG MIN }\end{array}$ \\
\hline & & & \\
98 & $189 / 00: 45$ & 5848.414 & 14432.604 \\
99 & $189 / 01: 00$ & 5848.369 & 14432.784 \\
100 & $189 / 01: 30$ & 5848.199 & 14433.102 \\
101 & $189 / 02: 00$ & 5848.009 & 14433.346 \\
102 & $189 / 02: 30$ & 5847.798 & 14433.759 \\
103 & $189 / 03: 00$ & 5847.614 & 14434.227 \\
104 & $189 / 03: 30$ & 5847.507 & 14434.474 \\
105 & $189 / 05: 00$ & 5846.770 & 14435.994 \\
106 & $189 / 05: 30$ & 5846.672 & 14436.257 \\
107 & $189 / 06: 00$ & 5846.422 & 14436.634 \\
108 & $189 / 06: 30$ & 5846.316 & 14437.085 \\
109 & $189 / 07: 00$ & 5846.172 & 14437.478 \\
110 & $189 / 07: 30$ & 5846.019 & 14437.991
\end{tabular}




$\begin{array}{llll}111 & 189 / 08: 00 & 5845.906 & 14438.302 \\ 112 & 189 / 08: 30 & 5845.798 & 14438.569\end{array}$

\section{SONOBUOY 7}

\begin{tabular}{cccc}
$\begin{array}{c}\text { LOCATION } \\
\text { NUMBER }\end{array}$ & $\begin{array}{c}\text { GMT TIME } \\
\text { DAY/HR:MN }\end{array}$ & $\begin{array}{c}\text { LATITUDE } \\
\text { DEG MIN }\end{array}$ & $\begin{array}{c}\text { LONGITUDE } \\
\text { DEG MIN }\end{array}$ \\
\hline & & & \\
113 & $189 / 08: 55$ & 5847.079 & 14437.322 \\
114 & $189 / 09: 00$ & 5847.078 & 14437.239 \\
115 & $189 / 09: 30$ & 5846.929 & 14437.800 \\
116 & $189 / 10: 00$ & 5846.687 & 14438.306 \\
117 & $189 / 10: 30$ & 5846.427 & 14438.522 \\
118 & $189 / 11: 00$ & 5846.253 & 14438.853 \\
119 & $189 / 11: 30$ & 5846.010 & 14439.396 \\
120 & $189 / 12: 00$ & 5845.804 & 14439.791 \\
121 & $189 / 12: 30$ & 5845.558 & 14440.099 \\
122 & $189 / 13: 00$ & 5845.207 & 14440.375 \\
123 & $189 / 13: 30$ & 5844.883 & 14441.005 \\
124 & $189 / 14: 00$ & 5844.540 & 14441.576 \\
125 & $189 / 14: 30$ & 5844.302 & 14442.255 \\
126 & $189 / 15: 00$ & 5844.029 & 14442.923
\end{tabular}


As a backup time base, WWVB time was continuously recorded by the 5-day recorders; particularly clear WWVB signals were recorded at 0700 GMT allowing the drift of the internal clocks to be robustly determined. Drift rates determined from the WWVB clock varied from 8 to $170 \mathrm{~ms} / \mathrm{day}$, although the average drift rate of the 5day internal clocks was about $30 \mathrm{~ms} /$ day.

On Julian Day 192, between 1510 and 2137 GMT, a constant time delay of 0.5 $s$ was introduced onto every wide-angle recorder. This time step occurred between the acquisition of the PWS and TACT lines. Because the time step occurred simultaneously at all 5-day recorders, we believe that the time break originated on the source vessel, the $\mathrm{R} / \mathrm{V}$ Geotide. The time step did not correspond to the time of tape changing and is thus unlikely to have originated within the 5-day recorders or the USGS Master Clock II in Valdez.

The cause of the time step on the $\mathrm{R} / \mathrm{V}$ Geotide has not been positively identified. During the time in question, however, the Cesium Standard used for navigation and as an external oscillator for the Kinemetric Clock Receiver on the R/V Geotide may have been replaced. We speculate that the replacement of the Cesium Standard introduced the $0.5 \mathrm{~s}$ step.

In any case, the available evidence supports the conclusion that the jump in times was discrete, not a progressive shift. As previously mentioned, the TACT and PWS lines were shot as overlapping pieces (Table 3). Wide-angle data for both of these lines show a $0.5 \mathrm{~s}$ step on these overlapping segments, even though the overlapping segments of the lines were acquired $51 / 6$ and $11 / 3$ days apart for the two lines. Thus, in the nearly 4 days between the overlap of the TACT and PWS lines no additional time step accumulated. We therefore removed the time step by subtracting $0.5 \mathrm{~s}$ from all reduced travel times after 2137 GMT on Julian Day 192.

\section{NAVIGATION}

Locations of signals generated by the airgun array towed by the $\mathrm{R} / \mathrm{V}$ Geotide were obtained from Loran-C. The time used to record Loran-C readings differed less than $1 \mathrm{~s}$ from the shot instant times, resulting in location errors less than 1 meter. The accuracy of Loran-C in the northern Gulf of Alaska is estimated to be 100 to $200 \mathrm{~m}$, based on the comparison of Loran-C and Global Positioning System (GPS) locations whenever both are available.

\section{DATA REDUCTION}

In the following we outline the steps taken to reduce the nearly 6 Gigabytes of wide-angle seismic data recorded by the 5-day instruments during the experiment. Digital navigation files were merged with the shot instant times to allow the calculation of source-receiver ranges for each source and receiver pair (see the Appendix). Sonobuoy locations obtained at 30 minute intervals were linearly interpolated to 
obtain locations for each shot instant time to allow the calculation of source-receiver ranges.

The Appendix describes in detail the reduction of the 5-day wide-angle data into seismic record sections. The first step included the playback and digitization of the 5-day analog recorder tapes into 5 minute blocks. These 5 minute digital blocks were then transferred to a VAX 11/785 computer where they were broken into discrete files (traces) for each shot origin time. Each file (trace) was assigned a source-receiver range and written to a SEG-Y format 6250 BPI digital tape. These tapes were then processed and wide-angle record sections were plotted using a DISCO seismic reflection processing package.

With minor differences, an identical scheme was used to reduce the data recorded by the GEOS recorder at Sites 17 and 18 . The 30 minute data files from the GEOS tapes were down loaded to a PDP 1170 minicomputer using the program RSGEOS written by Gary Maxwell. A typical 30-minute block consisted of 2 header blocks each 512 byte long and 180,000 2-byte integers of data. The header block contains the start time of the data file, the amplifier gain, and the sample rate. As the data were already in digital format, and the GEOS clock drift was negligible, the data reduction steps to calculate GMT times as for the 5-day data were omitted. Amplifier gains were then removed. Sonobuoy drift was accounted for by assuming a linear drift between sonobuoy locations determined at 30 minute intervals (Table 6). Sonobuoy locations corresponding to the time of the onset of the first arrival were used to calculate source-receiver ranges.

\section{RECORD SECTIONS}

The record sections obtained during each seismic reflection line are listed in Table 7. Each record section was written to a separate archival tape in SEG-Y format (see the Appendix), consisting of $23 \mathrm{~s}$ long traces reduced at $6 \mathrm{~km} / \mathrm{s}$. For the 5day data the traces start at $-4 \mathrm{~s}$ and have a $10.000071 \mathrm{~ms}$ sample rate whereas for the GEOS data the traces start at $-8 \mathrm{~s}$ and have a $10 \mathrm{~ms}$ sample rate. For the archival tapes, no further processing of the seismic data was performed. On these tapes produced from the 5-day data, with the exception for Site 3 (Middleton Island), channel 1 is the NS horizontal seismometer component, channel 2 is the vertical seismometer component, and channel 3 is the EW horizontal seismometer component. For Site 3 at Middleton Island, channel 1 is the vertical seismometer component, and channel 2 is the NS horizontal seismometer component.

Record sections were plotted with a reduction velocity of $6.0 \mathrm{~km} / \mathrm{s}$ for all receivers. The trace amplitudes were corrected for geometrical spreading by multiplying each trace amplitude by the range. Using DISCO software, the record sections were highpass filtered above $3 \mathrm{~Hz}$ and deconvolved. The predictive deconvolution effectively removed the reverberant source and receiver responses and allowed mid-crustal reflections and wide-angle refractions to be more easily identified. To 
enhance signal levels at large offsets, every 3 adjacent traces were then summed.

The record sections are high-quality and document that wide-angle recording of large volume airgun arrays can provide valuable constraints on crustal structure even in accretionary settings. The $50-\mathrm{m}$ trace spacing obtainable using this method made it possible to image first arrivals, refracted along the Wadati-Benioff zone, to sourcereceiver ranges of $290 \mathrm{~km}$ (Figure 3). Signal strength did not prove to limit our ability to record wide-angle data on any seismic line. Within Prince William Sound, prominent reflections from a mid-crustal reflector at $6 \mathrm{~s}$ (about $18 \mathrm{~km}$ depth) can be traced from near-vertical incidence to wide-angles at ranges of $50 \mathrm{~km}$ (Figure 4), where they become post-critical. These data thus provide important constraints on the RMS velocity of the upper and middle crust and hence the depth of these prominent reflections within Prince William Sound.

Particularly for the PWS line, large-amplitude converted shear wave arrivals, having a velocity of about $3.3 \mathrm{~km} / \mathrm{s}$, are present to ranges of $90 \mathrm{~km}$ (Figure 5). On the shelf beyond Prince William Sound the thicker sediments apparently greatly lowered the $\mathrm{P}$ to $\mathrm{S}$ conversion coefficient at the sediment-basement interface.

An example of a GEOS recording of a sonobuoy from the TACT line shown in Figure 6 clearly shows the crustal structure of the subducting oceanic crust. These data indicate that the crust in this vicinity has a relatively low average velocity. 
Table 7. Wide-angle Seismic Profiles

TACT Reflection Line

\begin{tabular}{|c|c|c|}
\hline $\begin{array}{l}\text { Site } \\
\text { No. }\end{array}$ & $\begin{array}{l}\text { Station } \\
\text { Name }\end{array}$ & Recorded Ranges $(\mathrm{km})^{*}$ \\
\hline 1 & Whittier & $304.9-6.6$ \\
\hline 2 & Zaikof Pt. & $210.1-3.9-97.8$ \\
\hline 3 & Middleton Isl. & $110.8-17.6-189.3$ \\
\hline 4 & Montague Isl. & $221.6-9.2-85.1$ \\
\hline 5 & Naked Isl. & $255.9-2.9-54.9$ \\
\hline 6 & Perry Isl. & 278.9-1.8-27.9 \\
\hline 7 & Smith Isl. & $57.5-3.8-65.1$ \\
\hline 8 & Signal Mtn. & 201.5-7.5-111.3 \\
\hline 9 & Suckling Hills & $183.8-140.4-162.4$ \\
\hline 10 & Kayak Isl. & $147.0-94.8-127.6$ \\
\hline 12 & Green Isl. & $47.8-33.3-77.6$ \\
\hline 13 & Busby Isl. & $268.3-45.2-87.9$ \\
\hline 14 & Stuart Creek & $294.1-130.6-176.6$ \\
\hline 15 & Shoup Bay & $292.7-76.0-105.7$ \\
\hline 16 & Culross Isl. & $290.2-2.8-11.6$ \\
\hline 17 & GEOS & $3.0-185.0$ \\
\hline
\end{tabular}

KAYAK Reflection Line

Site Station

No. Name Recorded Ranges $(\mathrm{km})^{*}$

2 Zaikof Pt. 27.7-180.1

3 Middleton Isl. 90.4-75.4-128.5

4 Montague Isl. 39.5-192.7

5 Naked Isl. 69.5-222.9

6 Perry Isl. 96.5-250.2

8 Signal Mtn. 13.2-166.1

9 Suckling Hills 148.3-57.4-58.4

10 Kayak Isl. 116.5-18.0-41.6

13 Busby Isl. 73.4-212.0

14 Stuart Creek 127.1-199.2

15 Shoup Bay 99.9-225.6 
16 Culross Isl.

111.9-265.7

17 GEOS

195.0-125.0-127.5

SUCKLING Reflection Line

Site Station

No. Name

Recorded Ranges (km)*

3 Middleton Isl.

138.2-112.2-121.6

9 Suckling Hills

24.6-151.5

10 Kayak Isl.

26.8-25.2-121.0

14 Stuart Creek

167.1-277.1

18 GEOS

114.6-7.3

PWS Reflection Line

\begin{tabular}{|c|c|c|}
\hline $\begin{array}{l}\text { Site } \\
\text { No. }\end{array}$ & $\begin{array}{l}\text { Station } \\
\text { Name }\end{array}$ & Recorded Ranges (km)* \\
\hline 1 & Whittier & $160.2-75.6-80.3$ \\
\hline 2 & Zaikof Pt. & $138.2-27.3-55.2$ \\
\hline 3 & Middleton Isl. & $127.3-103.7-154.8$ \\
\hline 4 & Montague Isl. & $137.6-14.5-47.3$ \\
\hline 5 & Naked Isl. & $153.1-14.2-28.9$ \\
\hline 6 & Perry Isl. & $156.5-41.3-47.2$ \\
\hline 7 & Smith Isl. & $146.3-4.4-33.1$ \\
\hline 8 & Signal Mtn. & $146.3-41.0-61.1$ \\
\hline 11 & Hanning Bay & $79.9-8.0-101.2$ \\
\hline 12 & Green Isl. & $115.6-3.7-64.3$ \\
\hline 13 & Busby Isl. & $196.0-176.2$ \\
\hline 14 & Stuart Creek & $277.2-108.6$ \\
\hline 15 & Shoup Bay & $226.6-47.2$ \\
\hline 16 & Culross Isl. & $156.0-57.5-63.2$ \\
\hline
\end{tabular}


GLACIER Reflection Line

\begin{tabular}{|c|c|c|}
\hline $\begin{array}{l}\text { Site } \\
\text { No. }\end{array}$ & $\begin{array}{l}\text { Station } \\
\text { Name }\end{array}$ & Recorded Ranges (km)* \\
\hline 1 & Whittier & $53.2-86.8$ \\
\hline 2 & Zaikof Pt. & $67.1-43.1$ \\
\hline 4 & Montague Isl. & $55.6-36.6$ \\
\hline 5 & Naked Isl. & $22.1-17.6-28.5$ \\
\hline 6 & Perry Isl. & 21.9-52.5 \\
\hline 7 & Smith Isl. & $34.1-24.7-27.5$ \\
\hline 8 & Signal Mtn. & $77.3-48.3$ \\
\hline 12 & Green Isl. & $62.6-55.9-56.5$ \\
\hline 13 & Busby Isl. & $41.3-24.4-24.5$ \\
\hline 14 & Stuart Creek & $131.7-110.3$ \\
\hline 15 & Shoup Bay & $63.4-55.3-55.5$ \\
\hline 16 & Culross Isl. & $36.6-69.0$ \\
\hline
\end{tabular}

*Middle range, when present, indicates closest approach of source vessel to receiver. 


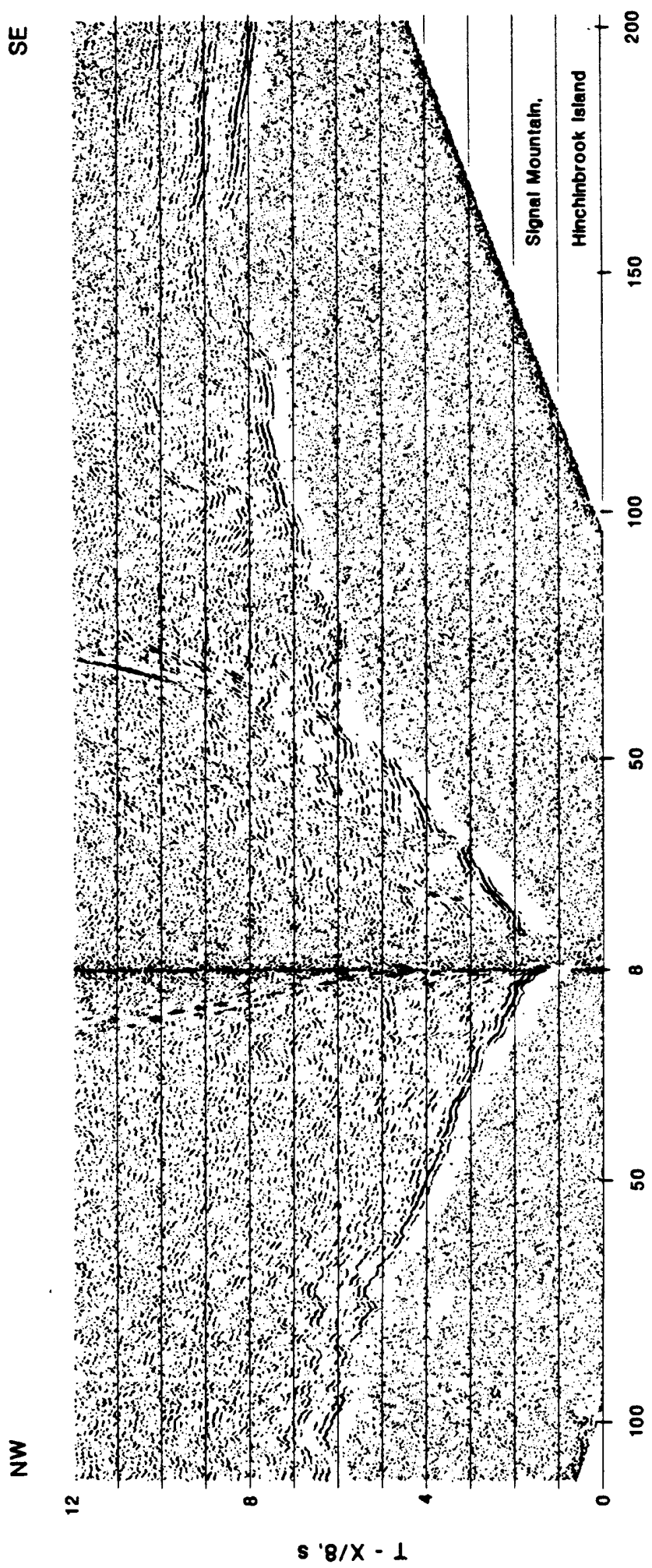

Figure 3. Recording of the TACT reflection line made at station on Signal Mountain, on Hinchinbrook Island (Site 8), showing clear arrivals to ranges of $200 \mathrm{~km}$. 


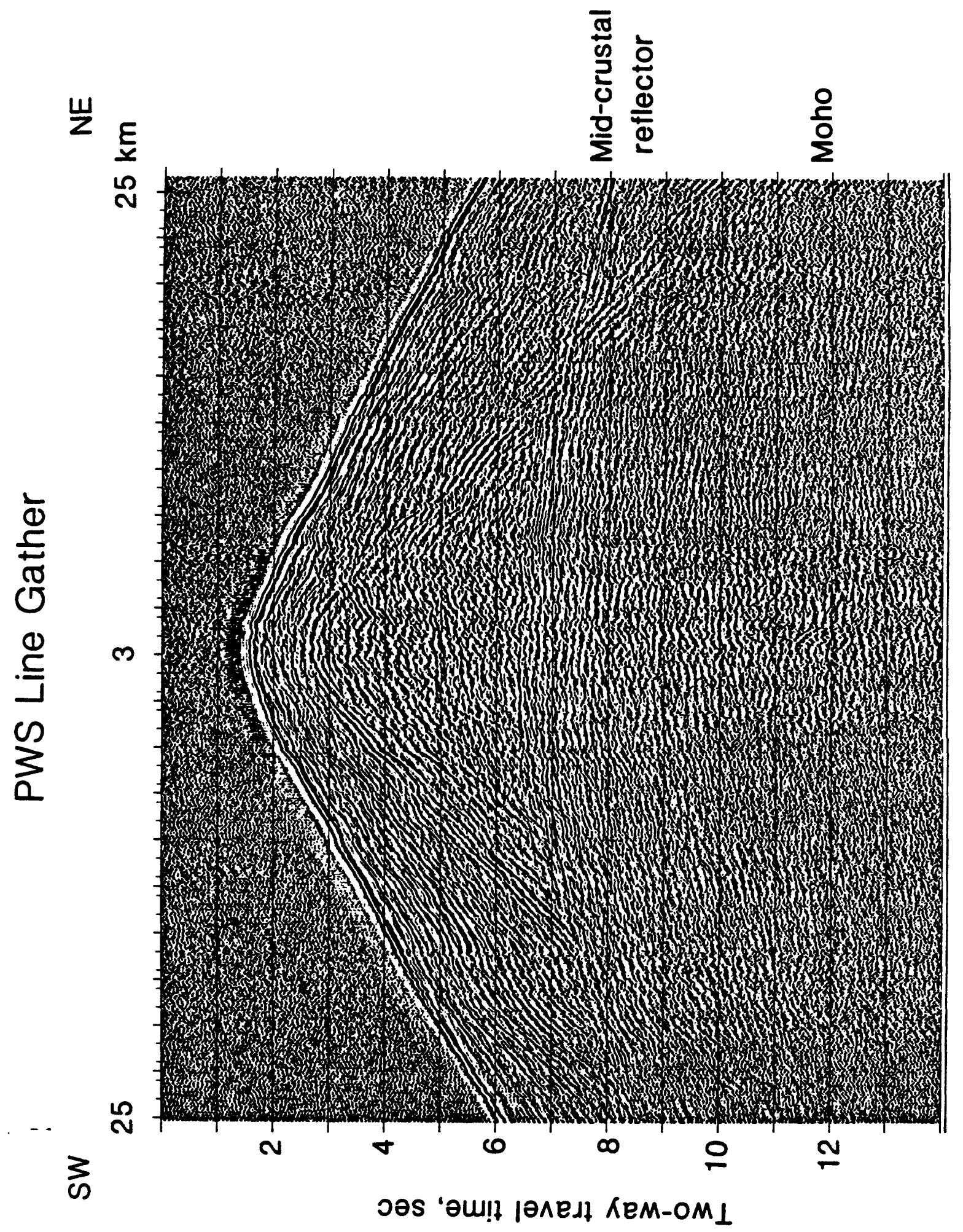

Figure 4. Common receiver gather recorded during the PWS reflection line at Smith Island (Site 7) showing prominent mid-crustal reflection at $6 \mathrm{~s}$ two-way travel time. 


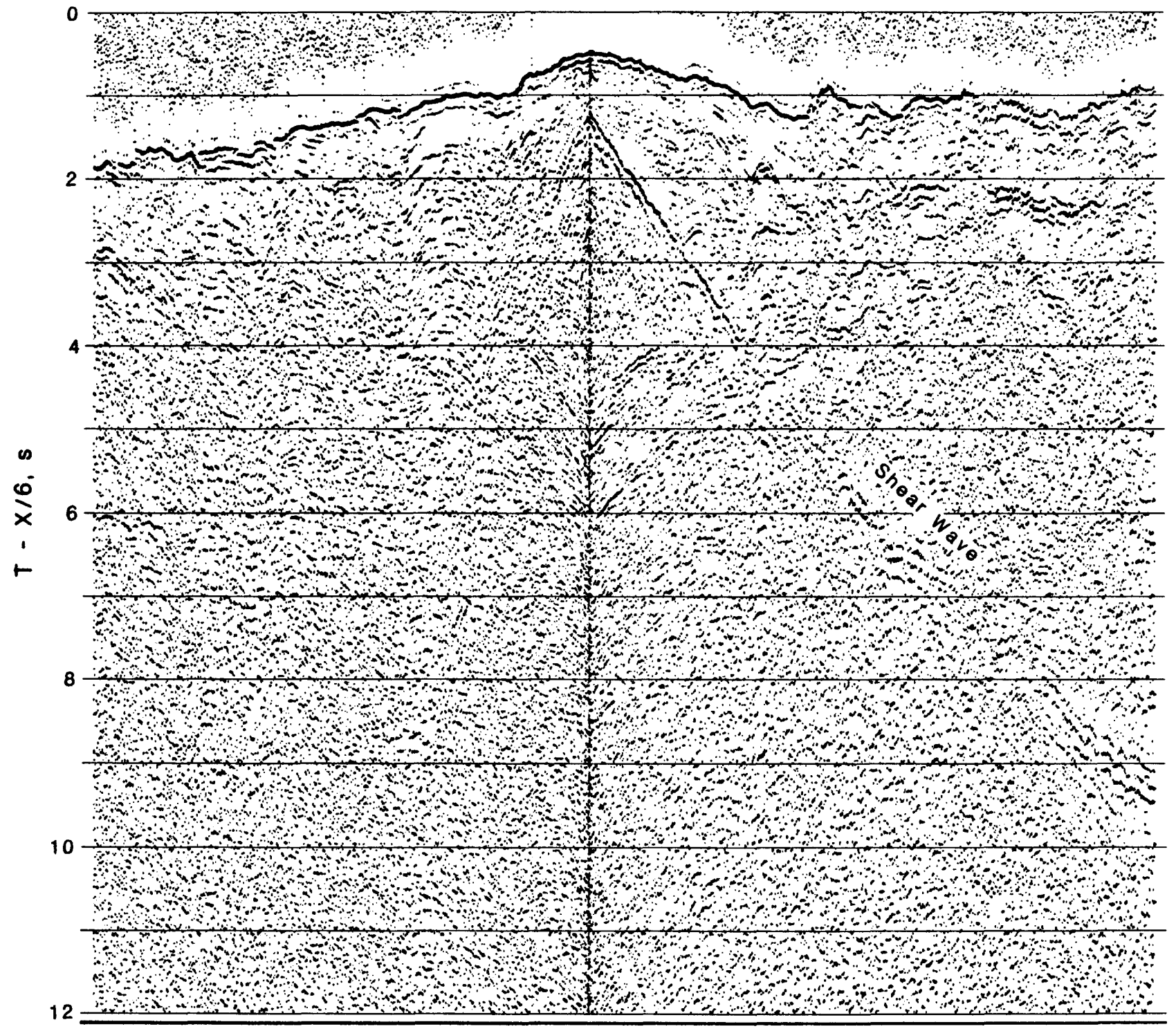

Figure 5. A seismic section from the TACT reflection line as recorded at Smith Island (Site 7) plotted with a reduction velocity of $6 \mathrm{~km} / \mathrm{s}$ showing converted shear wave arrivals. 


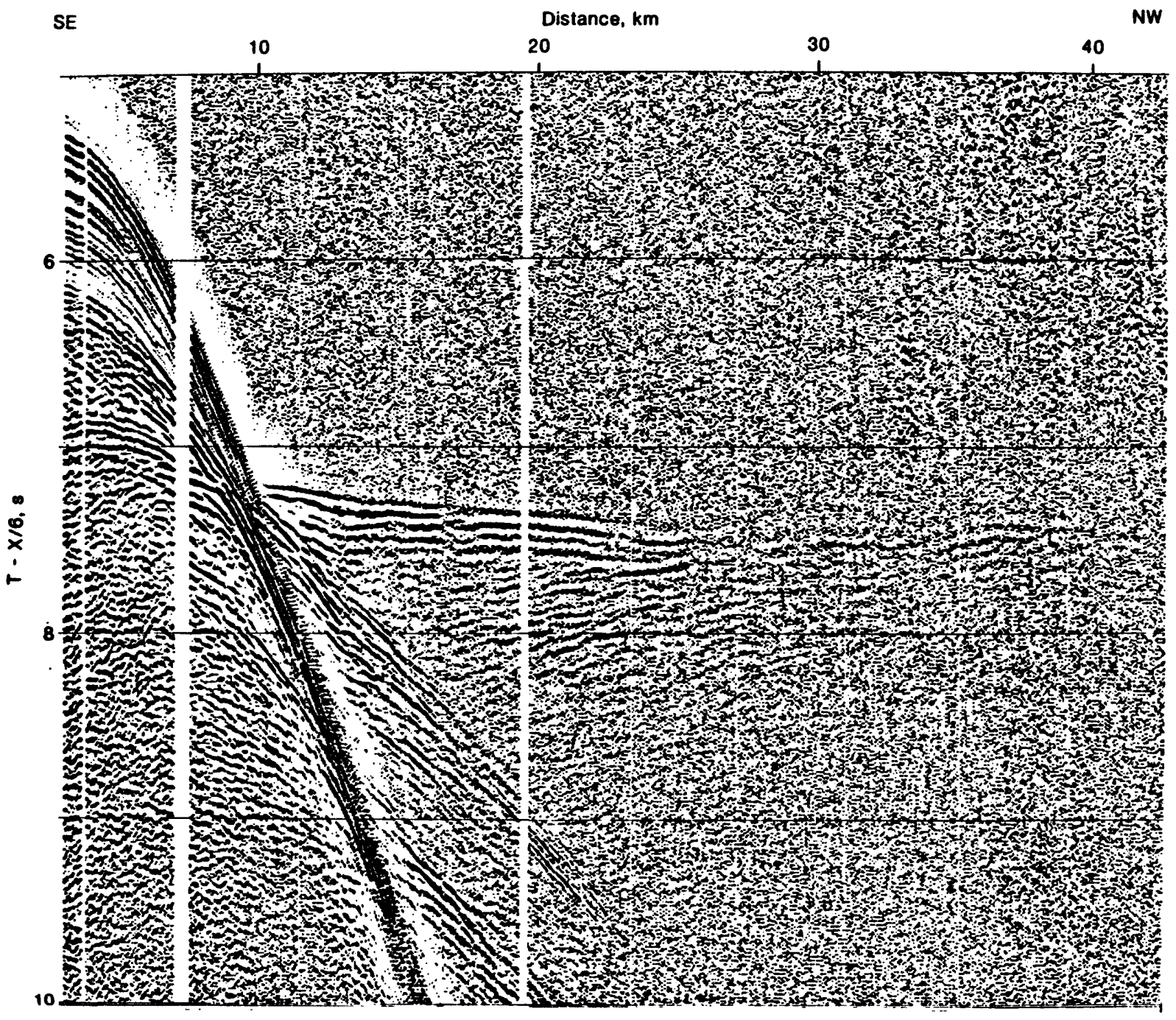

Figure 6. GEOS record of the sonobuoys deployed at the seaward end of the TACT line showing typical oceanic crustal structure at Site 17. 


\section{ACKNOWLEDGEMENTS}

We welcome this opportunity to thank the large number of individuals who contributed to the successful completion of this complex field experiment. Joe Stennis and Harry Von Sanford of Lamont-Doherty Geological Observatory (L-DGO), and Greg Miller and Jim Vaughan of the USGS lent equipment for the offshore recording. Peter Buhl (L-DGO), John Collins (Woods Hole Oceanographic Institution), and Perry Crampton (Scripps Institution of Oceanography) provided technical advice on the offshore recording. Gordon Grice of Digicon engineered the shot instant timing. Ed Criley, Dick Frei, Gary Fuis, Ron Kaderabek, Bob McClearn, Walter Mooney, Bob Page, John Rogers, and John Van Schaack of the USGS-Menlo Park, provided advice and technical support. Bill Abbott, Jill Schneider, and Jackie Sites of the USGS-Anchorage arranged a host of logistical matters. We thank the Captain and crew of the R/V Big Valley for their seamanship; Chief Burrus of the Cordova Coast Guard Station for his support of our helicopter operation; Len Paur and ERA Helicopters of Valdez for their able flying and assistance; Acting Head Ranger Dale Hom for permission to site recorders within the Chugach National Forest; and Steve Bridges of the FAA-Kenai for providing access to flights to Middleton Island.

John Coakley, Pat Hart, and Gonzalo Mendoza of the USGS-Menlo Park deployed the 5-day recorders. Chris Dietel of the USGS-Menlo Park oversaw the operation of the GEOS recorder on the R/V Big Valley. Gary Maxwell of the USGS-Menlo Park wrote the RSGEOS software to playback the 600-foot GEOS tapes. Will Kohler provided programming assistance. Steve Hughes, Steve Larkin, and Jill McCarthy helped us transfer the 5-day recorder data into SEG-Y format. Terry Bruns, Mike Fisher, and Eric Geist shared information on the TACT seismic reflection profiling onboard the R/V Geotide: Terry and Mike monitored the shot instant timing at sea. Jim Luetgert provided useful comments on an earlier draft of this report.

This work was supported by the Deep Continental Studies Program.

\section{APPENDIX: DATA REDUCTION}

In the following sections we describe the steps taken to reduce the analog 5-day recorder tapes to digital SEG-Y tapes and to display seismic record sections. The data reduction consisted of five steps: 1) conversion of the 5-day analog tapes to Pre-CUSP digital tapes; 2) merging of shot times and navigation coordinates of the source vessel; 3) the determination of clock drifts of the 5-day recorders; 4) conversion of Pre-CUSP digital tapes to SEG-Y digital tapes; and 5) the processing and display of wide-angle seismic sections using DISCO seismic reflection processing software. 
I. Five-day Analog Tape to Pre-CUSP Digital Tape Conversion

Playback and digitization of the $1 / 2$ inch analog 5-day tapes was performed in the USGS facility in Menlo Park.

\section{A. Preparation for Digitizing the 5-day Tapes}

Digitizing a 5-day tape requires a list of times, referred to as Target Times, to be digitized. These Target Times were entered into a file named TARGET.IP in the default directory of the Motorola PC in the Building 7 computer facility in Menlo Park. Because the array size of the programs used for subsequent processing was limited to 300 seconds of data, Target Times were generated at 4 minute intervals for the entire segment to be digitized. Forty-five Target Times, the equivalent of 3 hours of a 5-day tape, could be digitized per computer run, the maximum allowed by the memory on the Motorola hard disk.

B. Digitizing the 5-day Tapes

The 5-day tapes were digitized using computer program SUPER (written by Rex Allen) located in the default directory of the Motorola PC. This program digitized 5-day data at $10 \mathrm{~ms}$ intervals $(100 \mathrm{~Hz})$ in 5 minute blocks for those times specified in TARGET.IP at 4 minute intervals; the 1 minute overlap between files insured that no traces were lost. [The overlap was required because SUPER begins digitizing data anywhere from 17 seconds before to 6 seconds after the input Target Time.] After attempting to digitize blocks in the TARGET.IP list SUPER lists any Target Time not located on the analog tape due to IRIG-C time code problems.

Due to peculiarities in the setup of the Motorola PC, it is necessary to press the VME bus reset button to release the PC and tape drive for further operations.

The program SUPER stores the multiplexed digital data in the Motorola PC hard disk.

C. Output of the 5-day Tape Digitizer

The next step is to transfer the multiplexed digital data in the Motorola PC hard disk to a digital magnetic tape for further processing. The transfer to magnetic tape is performed using computer program FIVOUT (written by Rex Allen) located in the default directory of the Motorola PC. FIVOUT demultiplexes the data and writes files onto magnetic tape with a density of 
1600 BPI. Each data file consists of 16 blocks of data. The first block contained 256 bytes of header information written in a Pre-CUSP format. The digitized data were then written in 15 blocks, each 32256-bytes long, in DEC format. Each data block was demultiplexed and contained 16128 2-byte Integer words.

The 5-day tapes contain 8 tracks (channels) and the digitized traces contained 30016 2-byte Integer words. Channels 1 and 2 contained the high and low gain N/S horizontal geophone component. Channels 3 and 4 represented the high and low gain vertical geophone component. Channels 5 and 6 contained the low and high (i.e., reversed from the others) gain E/W horizontal geophone. Channels 7 and 8 were time codes with channel 7 representing the WWVB or (at the beginning and end of each tape) the Master Clock II IRIG-E time code. Channel 8 contained the IRIG-C internal clock time code.

D. Data Compression using TAPEDUPL

The final step in the digitizing sequence was to copy the 45 files from the 1600 BPI tape onto a 6250 BPI tape using the program PUB1:[REFRACT.MOSES.TACT.SEGY]TAPEDUPL (last modified by Will Kohler) on the VAX 11/785. The compressed 6250 BPI tape held up to 325 files, the equivalent of 21.6 hours of a 5-day tape.

II. Merging of Shot Times and Navigation Coordinates

A. Entry of Shot Instant Times

Shot times were entered manually into the VAX $11 / 785$ from printouts generated on the source vessel, the R/V Geotide. These shot times, accurate to the millisecond, were recorded using a Kinemetrics True Time Satellite Clock Receiver (Model 468).

B. Navigation Coordinates

Navigation coordinates were copied directly from a digital file supplied by Digicon to the VAX 11/785. The navigation file contained latitude and longitude of each airgun shot as well as the shot time accurate to the nearest second. 
C. Merging of Shot Instant Times and Navigation Coordinates

Computer program PUB1:[REFRACT.MOSES.TACT]COMP on the VAX $11 / 785$ was used to merge the navigation coordinates and the shot times into a single file. When there were more shot times than navigation coordinates (typically there were up to 10 more shot times than coordinates), the corresponding number of shot times were simply eliminated. To match the shot time to the corresponding navigation coordinate, the shot time was compared to the time associated with the navigation coordinate. Program COMP eliminated any shot time not within one second of a navigation time.

\section{Station Locations}

In the field, the locations of the 5-day recorders were plotted on USGS topographic maps having a scale less than or equal to $1: 63,360$. The latitude and longitude of each recorder was digitized using computer program MAP2 (written by Will Kohler) on the PDP 11/23 used for digitizing cassette recorder data and were also verified manually. The latitude and longitude of each recorder was then written into a VAX 11/785 file named STLOC.DAT.

E. Calculation of Reduced Travel Times

Program PUB1:[REFRACT.MOSES.TACT]TACTTIME0.EXE on the VAX $11 / 785$ computed the distance and azimuth from each shot to each station. Using the calculated source-receiver range, the reduced origin time was calculated using a reduction velocity of $6 \mathrm{~km} / \mathrm{s}$. To verify these calculations, the time difference between shots, the distance between shots, and the speed of the source vessel between shots were computed for each shot. When any of these values exceeded reasonable bounds they were written into a separate computer file so that they could be checked and corrected.

\section{Determination of Clock Drift}

\section{A. WWVB Time Code}

Because the internal clock within a 5-day recorder drifts up to $170 \mathrm{~ms} /$ day the reduced shot times had to account for this drift. The internal clock drift was determined using the simultaneously recorded WWVB time code. On channel 7 the 5-day recorder captured the WWVB time code transmitted from Denver, Colorado. This time code is a $1 \mathrm{~Hz}$ code which, except 
for a 25 to 30 millisecond transmission delay to Prince William Sound was accurate to within $4 \mathrm{~ms}$.

During our experiment WWVB produced an easily measured signal for approximately $3 \mathrm{hrs} / \mathrm{day}$ centered at $0700 \mathrm{GMT}$ in the vicinity of Valdez, Alaska. By digitizing a block of time centered on this window, we were able to directly compare the internal clock and WWVB time. This comparison was performed using a program written by us called PUB1:[REFRACT.MOSES.TACT.SEGY]SEGY-TEST.EXE which printed the digitized clock signals, allowing us to determine the difference in the time codes. We applied a least-squares fit to these estimates for each fiveday interval to obtain the drift of the internal clock of the 5-day recorders. The drift rate was then entered into the program TACT-SEGY.EXE as described in the next section.

\section{B. Master Clock II}

During the field acquisition, an IRIG-E $(10 \mathrm{~Hz})$ Master Clock II signal was written on the beginning and end of each 5-day tape in place of the WWVB signal. Unfortunately, this IRIG-E time code could not be digitized using program SUPER as described above since the $10 \mathrm{~Hz}$ signal lies at the upper end of the digitizer discriminator range. It was possible, however, to capture this signal by digitzing the tape using a logic analyzer. Recorded IRIG-E and IRIG-C signals were then compared to determine the total offset between the Master Clock II time and the 5-day internal clock time. After correction for the Master Clock II drift, this offset was used to further refine the internal clock drift.

IV. Pre-CUSP Digital Tape to SEGY Tape Conversion using Program TACTSEG.EXE

A. Introduction

The conversion of the 5-minute long digital files in Pre-CUSP format to 20 -second long SEGY formatted shot records (traces) was performed using an interactive program written by us for this purpose called PUB1:[REFRACT.MOSES.TACT.SEGY]TACT-SEGY.EXE on the VAX $11 / 785$. This program requires 2 tape drives (one for the input tape and one for the output tape) and converts between 400 and 1000 shots per hour. TACT-SEGY.EXE needs the reduced shot times and source/receiver location information output by the program TACTTIMEO described in Section II.E. 


\section{B. Tape Formatting}

The program TACT-SEGY.EXE requests whether any files should be skipped on either the input or output tape. This option allowed for partial line conversions requiring less than the normal 3 to 6 hours of computer time. Information regarding the reel and trace headers was then requested. If a new line was to be converted the program began at shot and file number 1. If the program was to finish conversion of a previously started line, then the shot and file numbers were read from a file called FILENO.DAT on PUB1:[REFRACT.MOSES.TACT.SEGY]. File numbers were written sequentially whereas the shot number used was the actual sequence of the shot in the shot instant file.

The program TACT-SEGY.EXE next asked whether a new tape reel was to be used. If an old tape reel was to be completed no new reel headers were written. If a new tape reel was to be written the program requested a tape reel number. Two reel headers were then written. The first reel header was a 3200-byte file consisting of 40 80-character EBCDIC cards of general project information found in SEGYREELHEADER.DAT. These EBCDIC characters were byte swapped from DEC to standard SEGY-IBM format. The second reel header was a 400-byte block of 2- and 4-byte integers containing specific reel and line information. The location of each header value as defined by Barry et al. (1975) was modified as described by Luetgert et al. (1990). The values in the second header were also byte swapped from DEC to SEGY-IBM format.

\section{Determination of Start Times of the 5-Minute Blocks}

At this point, the program TACT-SEGY.EXE was nearly ready to resample the 5 minute digital blocks into 20-second-long traces. 5-minute file headers were first read from the input tape and the 2- and 4-byte values were word and byte swapped from Pre-CUSP to DEC format. Then the time of the first sample in the 5 minute file was determined by examining the IRIG-C signal on channel 8 in several steps.

The most complex of these steps was the determination of the digitization rate, which we found to vary within each 5 minute block of digitized data due to slight variations in the recording speed of the 5-day recorders. In program TACT-SEGY.EXE it is possible to specify either a constant or nonconstant digitizing rate. If a constant digitizing rate was requested, a sample rate of $10.000071 \mathrm{~ms}$ was used as determined from testing. If a non-constant rate was requested, the program determined the digitizing rate by reading the IRIG-C time code on channel 8 and computing the average 
number of samples between every half-second mark in the 5 minute file. This method proved highly accurate unless the IRIG-C time code had a low-signal to noise ratio. Although the program attempts to remove noise spikes in the time code by filtering, the accuracy of our determination of the digitizing rate was degraded by the noise spikes. The data were then resampled to the nominal sample rate of $10.000071 \mathrm{~ms}$.

Upon determining the digitizing rate the IRIG-C signal was then read to locate the first minute mark. By counting backward from the sample representing the minute mark the first sample time was determined. Finally, the drift of the internal clock was removed.

\section{Trace Conversion to SEG-Y Format}

At this point, traces could be selected using shot instant times corrected for source-receiver offset assuming a velocity of $6 \mathrm{~km} / \mathrm{s}$. If the shot occurred before the first sample in the five minute file the program skipped to the next shot instant time. Similarly, if the shot occurred less than 2301 samples before the last sample the program skipped to the next five minute file.

Having defined individual traces, program TACT-SEGY.EXE was now ready to write the traces onto the output SEG-Y tape. To conserve tape space on the output tape, the program wrote only the three high gain seismic channels to SEG-Y tape so there are 3 data blocks (traces) for each shot. Trace 1 contains the high gain N/S horizontal seismometer component, Trace 2 contains the high-gain vertical component, and Trace 3 contains the high-gain E/W horizontal seismometer component. Each trace includes a 240-byte trace header of 2- and 4-byte integers describing the specific trace and 2301 2-byte integer data samples. The location of each value in the trace header as described by Barry et al. (1975) was slightly modified as described by Luetgert et al. (1990). All trace integer values were byte swapped from DEC to SEGY-IBM format and are written in SEGY-IBM16INT format. At the completion of the conversion of the 5 minute files the program then wrote an output file, named FILENO.DAT which contained the last file number written on the tape and the next shot number to be written.

F. Final Formatting of the SEGY Tape

An End of Tape (EOT) mark is written at the end of a tape upon completion of writing all traces recorded along a wide-angle line. Typically, a 12-inch 6250 BPI SEG-Y tape held 4000 3-component traces. 
V. Processing and Display of the SEG-Y Digital Tapes

A. The final SEG-Y tapes were taken to the USGS DISCO seismic reflection processing center in Menlo Park for processing and display. The DISCO modules used to process the data included GIN, FILTER, VSTACK, EXPAMP, DECON, and RECPLOT. The following sections describe in greater detail the functions performed by each module.

B. Data Entry using GIN

GIN is the DISCO module which read SEG-Y tapes and reformatted them into internal DISCO format. GIN identifies traces either by FFID, SHOT, CHAN, or OFFSET. FFID is the sequential file number of each trace. SHOT is the shot number. CHAN is the channel number $(1=N / S, 2=$ Vertical, $3=\mathrm{E} / \mathrm{W}$ seismometer). OFFSET is the source-receiver offset in meters. FFID, SHOT, CHAN, and OFFSET are all 4-byte integers and are located in trace header at byte $9,13,17$, and 37 , respectively.

C. Bandpass Filtering using FILTER

Spectra revealed that the signal strength on the 5-day tapes was concentrated between 6 and $11 \mathrm{~Hz}$ whereas the noise was peaked between 1 and 4 $\mathrm{Hz}$; noise levels above $11 \mathrm{~Hz}$ were negligible. We therefore applied a 3-7 $\mathrm{Hz}$ highpass filter which eliminated all noise below $3 \mathrm{~Hz}$.

D. Stacking Traces using VSTACK

High-signal coherence on adjacent traces separated by only $50 \mathrm{~m}$ allowed us to stack 3 adjacent traces without discernible signal distortion. This stacking was performed after reduction of the record section to a velocity of $6 \mathrm{~km} / \mathrm{s}$.

E. Correction for Geometrical Spreading using EXPAMP

DISCO module USR\$DISK:[ERIC.SOURCE.EXPAMP]EXPAMP, written by Eric Geist, was used to apply a correction for geometrical spreading losses. We applied a gain of range to the first power.

F. Deconvolution using DECON

After repeated experimentation with DISCO deconvolution parameters, a predictive deconvolution operator of $500 \mathrm{~ms}$ length, with a gap of $10 \mathrm{~ms}$, 
and $0.1 \%$ white noise was found to produce the best wavelet compression. The deconvolution operator was designed on a shot by shot basis with a design gate $750 \mathrm{~ms}$ long beginning at the arrival time of the first arrival. The operator thus obtained was applied to the entire trace. The deconvolution produced no discernible phase shift.

G. Final Display of Wide-Angle Seismic Profiles using RECPLOT

Final displays of wide-angle record sections were produced using DISCO module USR\$DISK:[ERIC.SOURCE.RECPLOT]RECPLOT, written by Eric Geist. 


\section{REFERENCES}

Barry, K.M., D.A. Cravers, and C.W. Kneale, Recommended standards for digital tape formats, Geophysics, 40, 344-352, 1975.

Borcherdt, R. D., J. B. Fletcher, E. G. Jensen, G. L. Maxwell, J. R. VanSchaack, R. E. Warrick, E. Cranswick, M. J. S. Johnston, and R. McClearn, A general earthquake observation system (GEOS), Bulletin of the Seismological Society of America, 75, 1783-1825, 1985.

Bruns, T. R., Tectonics of the Yakutat block, an allochthonous terrane in the northern Gulf of Alaska, U. S. Geological Survey Open-file Report 85-13, 112 pp., 1985.

Criley, E., and J. Eaton, Five-day recorder seismic system, U.S. Geological Survey Open-file Report 78-266, 85 pp., 1978.

Lee, M. W., W.F. Agena, and D.R. Hutchinson, Processing of the GLIMPCE multichannel seismic data, U.S. Geological Survey Open-file Report 88-225, 46 pp., 1988.

Luetgert, J., S. Hughes, J. Cipar, S. Mangino, D. Forsyth, and I. Asudeh, Data report for O-NYNEX the 1988 Grenville-Appalachian seismic refraction experiment in Ontario, New York, and New England, U. S. Geological Survey Open-file Report 90-426, 51 pp., 1990.

Page, R.A., Plafker, G., Fuis, G.A., Nokleberg, W.J., Ambos, E.L., Mooney, W.D., and Campbell, D.L., Accretion and subduction tectonics in the Chugach Mountains and Copper River basin, Alaska: Initial results of the Trans-Alaska Crustal Transect, Geology, 14, 501-505, 1986.

Wilson, J.M., P. Meador, and G. Fuis, Data report for the 1985 seismic-refraction survey, south-central Alaska, U.S. Geological Survey Open-file Report 87-440, 78 pp., 1987. 